\title{
Improvement Of Rheological Properties Of Al-Dura Asphaltic Binders Using Chemical Modifiers
}

\author{
Dr. Qays Mothanna Ammouri
}

Ministry of Oil / Petroleum Research and Development Center

\begin{abstract}
$\underline{\text { Abstract }}$
Treating Iraqi asphaltic binder produced from Al - Dura refinery by either oxygenation or $4 \%$ sulfur or $4 \%$ nitric acid improved the penetration from $241 \mathrm{~mm}$ down to $92 \mathrm{~mm}$, and from (68 - 63 ) $\mathrm{mm}$ also it and improved the softening point from $39{ }^{\circ} \mathrm{C}$ up to $49{ }^{\circ} \mathrm{C}, 50{ }^{\circ} \mathrm{C}, 52$ ${ }^{\mathrm{O}} \mathrm{C}$ respectively and it, improved the ductility from $73 \mathrm{~cm}$ up to $100 \mathrm{~cm}$, $102 \mathrm{~cm}, 106 \mathrm{~cm}$ respectively.

were included when subjecting the treated asphaltic binder samples to (sunlight, water immersion, $1 \mathrm{~kg}$ load, both sunlight and $1 \mathrm{~kg}$ load, both water immersion and $1 \mathrm{~kg}$ load, both sunlight and water immersion and both sunlight, water immersion and $1 \mathrm{~kg}$ load). Compared with base asphaltic binder supplied directly from refinery without treatment which failed immediately during one week.
\end{abstract}

\begin{abstract}
When subjecting these treated asphaltic binders to Iraqi environmental conditions, the rheological properties will not changed during 14 months. The studied environmental conditions
\end{abstract}




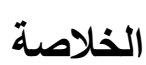

ان معاملة الر ابط الاسفلتي المنتج من

مصفى الدورة بعملية نفخ الاوكسجين او

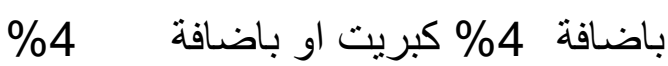

حامض النتريك حسب اختر اقية الر ابط

الاسفلتي من 241 ملم الى 92 ملم ، 68

ملم و 63 ملم على التوالي وحسب نقطة الليونة من 39 م الى 49 م ، 50 م و 52 م على التو الي ، ايضا" حسب الامتدادية من من مالـ 73 سم الى 100 سم ، 102 سمو 106 سم على التو الي و عند اخضاع هذه الر ابطة الاسفلتية المعالجة الى الظروف البيئية العر اقية فان الخواص الريولوجية لها لم لم لئل تتغير خلال 14 شهر ـ ان الظروف البيئية التي تم دراسة تأثير ها على نماذج الر ابط الاسفلتي المعالج شملت كل من ضوء الثمس ، الماء ، الحمل ، ضوء الثمس لهم و الحمل سوية ، الماء و الحمل سوية ، ضوء الثمس و الماء سوية وكذلك ضوء الثمس و الماء و الحمل سوية ـ لقد تم مقارنة تأثير تللك الظروف على الر ابط الاسفلتي المعالج بالر ابط الاسفلتي الاساس المجزز مباثرة من المصفى بدون اضافات و الذي فنثل

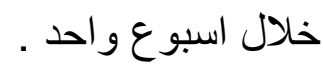

\section{$\underline{\text { Introduction }}$}

Asphaltic binders are multiphase systems with rheological behavior resemble in that of polymeric substances. The Primitive structure of asphaltic binder is a combination of asphaltenes, resins and oil phases with average ratio of approximately $30 \%, 20 \%$ and $50 \%$ respectively (John et al., 1999).

Asphaltic binders that produced from refineries are highly unstable and have high limitations to use in paving of roadways, so it is important to treat the asphalt by different modifiers in order to improve its rheology and stabilize it to remain flexible at lower temperatures, yet stable at higher temperatures (Roman et al., 1999).

Many workers made attempts to improve the rheological behavior of asphaltic binder by 
adding different chemical modifiers

to base asphalt such as oxygen, acids and metalloids. David et al. (1990) tried to improve the rheological properties of asphaltic binder by oxygenation at $260{ }^{\circ} \mathrm{C}$ for 6 hours while Glanville et al. (1992) made attempts to improve the rheological properties of asphaltic binder by adding hydrochloric acid to base asphalt also, Arnold et al. (1995) tried to improve the rheological properties of asphaltic binder by adding organic salts (i.e. sodium acetate, potassium benzoate, etc.) to base asphalt.

Most roadways provinces lack of durability because of two important reasons, the first one is that the asphaltic binders produced from refineries have low rheological properties made it not available to use in paving of roadways, while the second reason is that the wide temperature difference between summer and winter that cause the need to use asphaltic binders having high softening point to sustain hot summer conditions with enough ductility to resist low winter temperatures.

This research attempts to study the effects of adding different chemical modifiers on the improvements of rheological behavior of base asphalt produced from refinery.

On the other hand the effects of weathering conditions on the life time of treated asphaltic binders degradation resistance were studied in order to compare improvement of binder with addition chemical modifiers with binder without additives .

\section{$\underline{\text { Experimental Work }}$}

\section{Oxygenation of Asphalt}

The base asphalt was heated to a temperature about $80 \mathrm{OC}$ in order to melt it to liquid phase and then the liquid asphalt poured into treatment vessel. The temperature of the asphalt in the vessel was raised slowly at constant atmospheric pressure to around $220-$ $2600 \mathrm{C}$ by direct mental heating. A 
0.5 weight percent of $\mathrm{CuSO} 4$ was added to the asphalt as catalyst. Air at $60 \mathrm{OC}$ was blowing through the melted asphalt by using air distributer at flow rate $0.5-2.0$ $\mathrm{m} 3 / \mathrm{hr}$ for 2 hours. Water produced as byproduct was removed from steel vessel by vacuum after each 15 minutes. The treated asphaltic binder product was discharged from the vessel and then cooled.

\section{Sulfurisation of Base} Asphalt

Melted base asphalt at $80^{\circ} \mathrm{C}$ was poured into treatment vessel. The temperature of the asphalt in the vessel was raised slowly to around $200-220{ }^{\circ} \mathrm{C}$ by direct mental heating. Sulfur as $1-4$ weight percent was added to the asphalt and mixed continuously with asphalt for 2 hours. The treated asphaltic binder final product was discharged from the vessel and left to cool.

\section{Nitration of Base Asphalt}

Melted base asphalt at $80^{\circ} \mathrm{C}$ was poured into the steel vessel. The temperature of the asphalt in the vessel was lowered to $70{ }^{\circ} \mathrm{C}$. Concentrated nitric acid (64\% Conc.) as 1 - 4 weight percent was added slowly and gradually to the asphalt and mixed continuously with asphalt for one hour. The treated asphalt binder final product was discharged from the bottom of the vessel and then cooled.

\section{Results and Discussion}

Effects of Oxygenation on Rheology of Asphaltic Binder

The results obtained are indicated that the increasing of air flow rate which blows through base asphalt to $2 \mathrm{~m}^{3} / \mathrm{hr}$ at $260{ }^{\circ} \mathrm{C}$ in the presence of copper sulfate catalyst for 2 hours improved the penetration from $241 \mathrm{~mm}$ down to $92 \mathrm{~mm}$ and improved the softening 
point from $39{ }^{\circ} \mathrm{C}$ up to $49{ }^{\circ} \mathrm{C}$, while the ductility was improved from 73 $\mathrm{cm}$ up to $100 \mathrm{~cm}$ as shown in Figs.1, 2, and 3.

The improved results obtained by this study on adding copper sulfate catalyst to base asphalt indicated that the penetration and the softening point are improved by $70 \%$ and $32 \%$ respectively, while the ductility improved up to $100 \mathrm{~cm}$. Also, the results indicated that using of copper sulfate reduce the time of oxygenation as shown in Figs.4, 5 and 6.

These results are almost similar to the results obtained by David (1990) who improved the penetration and the softening point of Venezuelan base asphalt by $68 \%$ and $32 \%$ respectively and improved the ductility from $75 \mathrm{~cm}$ up to 100 $\mathrm{cm}$, compared without using copper sulfate catalyst . 


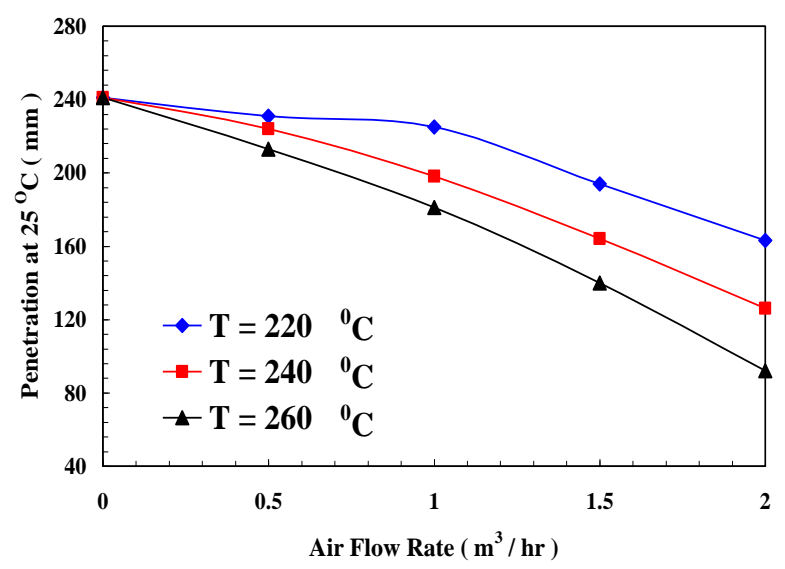

Fig.(1) Penetration vs. Air Flow Rate

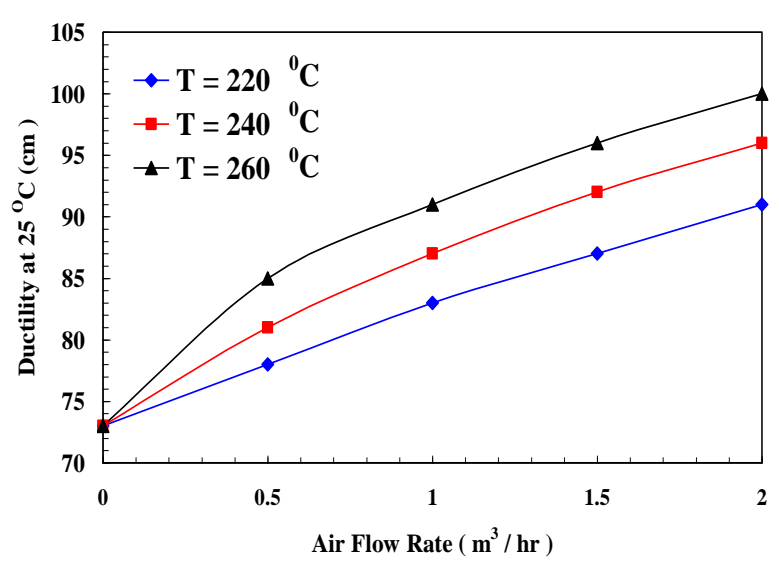

Fig.(3) Ductility vs. Air Flow Rate

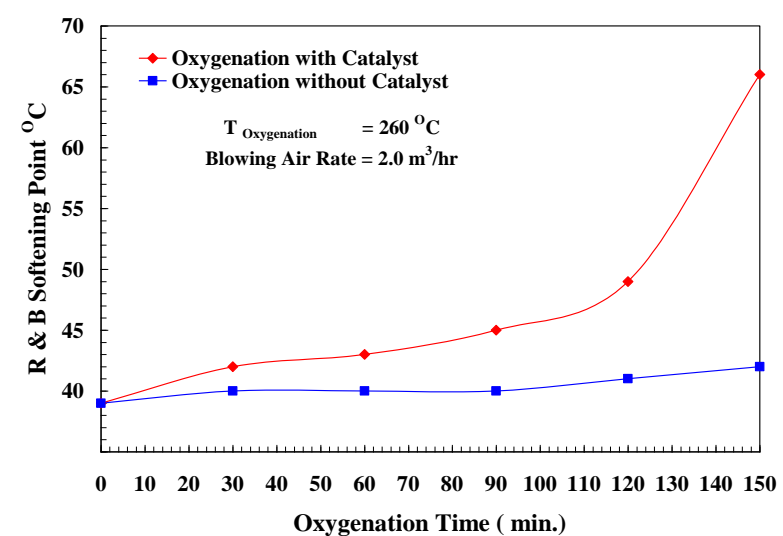

Fig.(5) Softening Point vs. Oxygenation Time

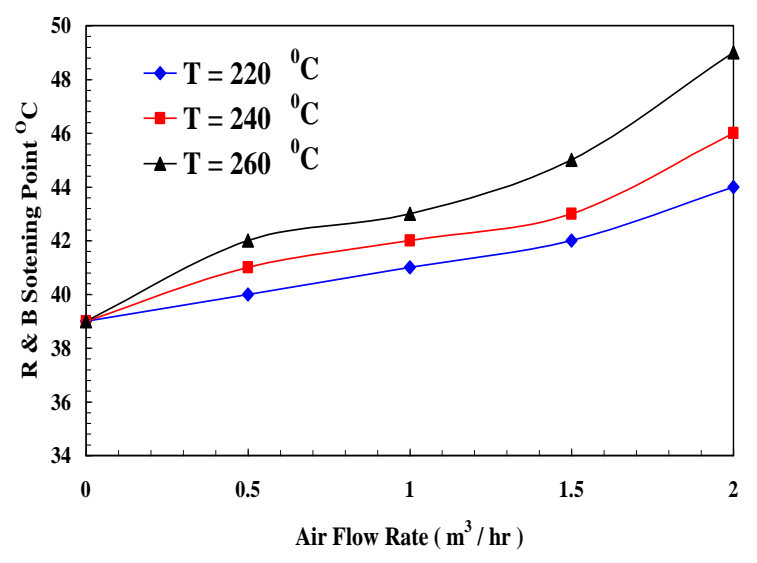

Fig.(2) Softening Point vs. Air Flow Rate

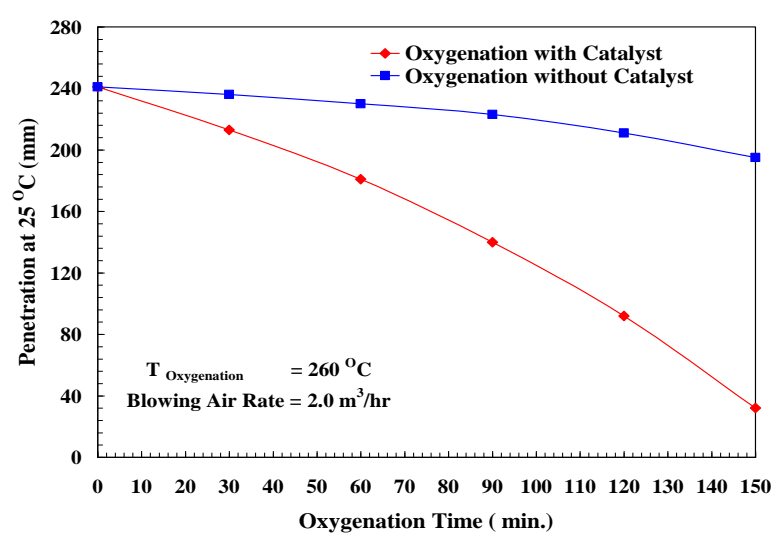

Fig.(4) Penetration vs. Oxygenation Time

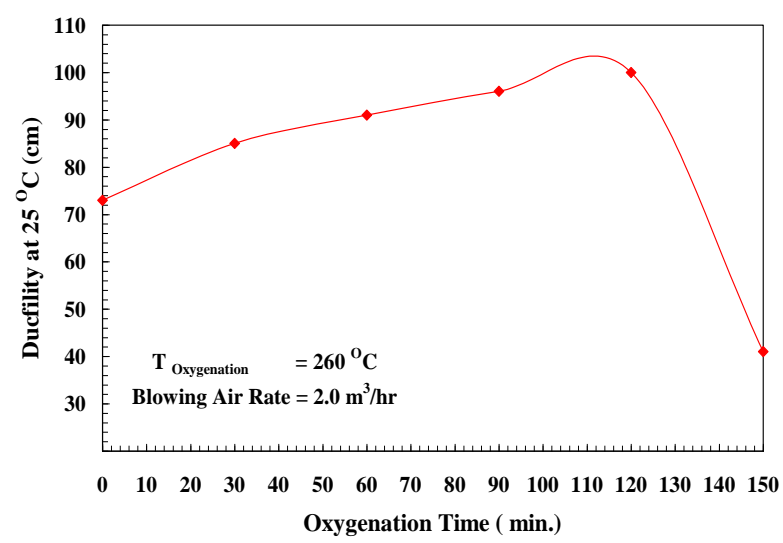

Fig.(6) Ductility vs. Oxygenation Time 


\section{Effects of Sulfur Addition on}

\section{Rheology of Asphaltic Binder}

The results obtained are indicated that the addition of sulfur to base asphalt at $200{ }^{\circ} \mathrm{C}$ for 2 hours was not affected the rheological properties of the binder, while addition $4 \%$ sulfur to the base asphalt at $220{ }^{\circ} \mathrm{C}$ for 2 hours improved the penetration from 241 $\mathrm{mm}$ down to $68 \mathrm{~mm}$ and improved the softening point from $39{ }^{\circ} \mathrm{C}$ up to $50{ }^{\mathrm{O}} \mathrm{C}$, while the ductility was improved from $73 \mathrm{~cm}$ up to $104 \mathrm{~cm}$ as shown in Figs. $(7,8)$ and $(\mathbf{9})$.

Also, the results indicated that the addition of $5 \%$ sulfur to base asphalt improved the penetration from $241 \mathrm{~mm}$ down to $24 \mathrm{~mm}$ and improved the softening point from $39{ }^{\circ} \mathrm{C}$ up to $76{ }^{\circ} \mathrm{C}$, but reduced the ductility from $73 \mathrm{~cm}$ down to 58 $\mathrm{cm}$. The decreasing of ductility made the asphaltic binder not suitable to use as paving binder.

The improved results obtained by this study on adding $4 \%$ sulfur to base asphalt indicated that the penetration and the softening point improved by $82 \%$ and $35 \%$ respectively, while the ductility was improved up to $104 \mathrm{~cm}$. These results are slightly better than obtained results by oxygenation.

The results obtained by adding $4 \%$ sulfur to the base asphalt are almost similar to the ideas that reported by Gabrille (2005) who stated that adding 5\% sulfur to Mexican asphalt improved the penetration by $70 \%$ and improved the softening point by $33 \%$ also, improved the ductility from $72 \mathrm{~cm}$ up to $100 \mathrm{~cm}$.

- Effects Of Nitric Acid Addition On Rheology Of Asphaltic Binder

The results obtained are indicated that adding $4 \%$ of nitric acid (64\% conc.) to base asphalt at 70 OC for 1 hour improved the penetration from $241 \mathrm{~mm}$ down to $63 \mathrm{~mm}$ and improved the softening point from 39 OC up to $52 \mathrm{OC}$ also, 
improved the ductility from $73 \mathrm{~cm}$ up to $106 \mathrm{~cm}$ as shown in Figs. 10, 11 and 12 respectively.

Also, the results indicated that the addition of $5 \%$ nitric acid to the base asphalt improved the penetration from $241 \mathrm{~mm}$ down to $26 \mathrm{~mm}$ and improved the softening point from 39 OC up to 75 OC, but reduced the ductility from $73 \mathrm{~cm}$ down to $42 \mathrm{~cm}$. The decreasing of ductility made the asphalt binder not suitable to use in paving.

The improved results obtained by this study on adding $4 \%$ nitric acid to base asphalt indicated that the penetration and the softening point improved by $84 \%$ and $42 \%$ respectively, while the ductility was improved up to $106 \mathrm{~cm}$.These results are almost similar to the ideas that reported by Henry (2007) who did not state the results data and are slightly better than obtained results by adding $4 \%$ sulfur. 


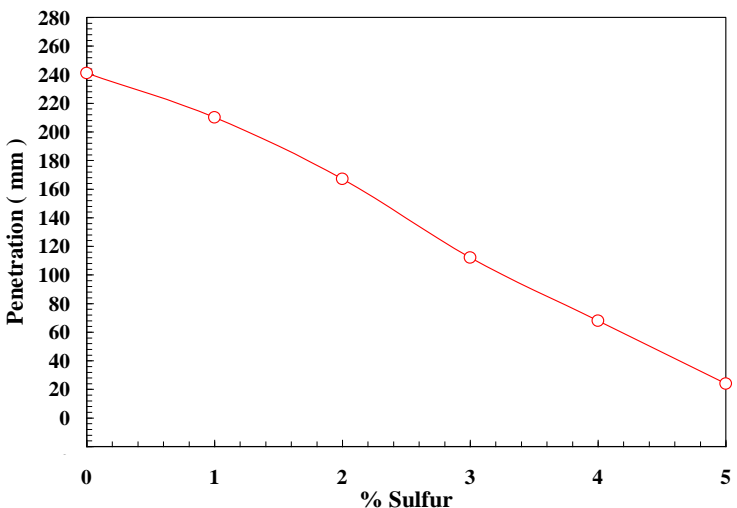

Fig.(7) Penetration vs. Sulfur Percent

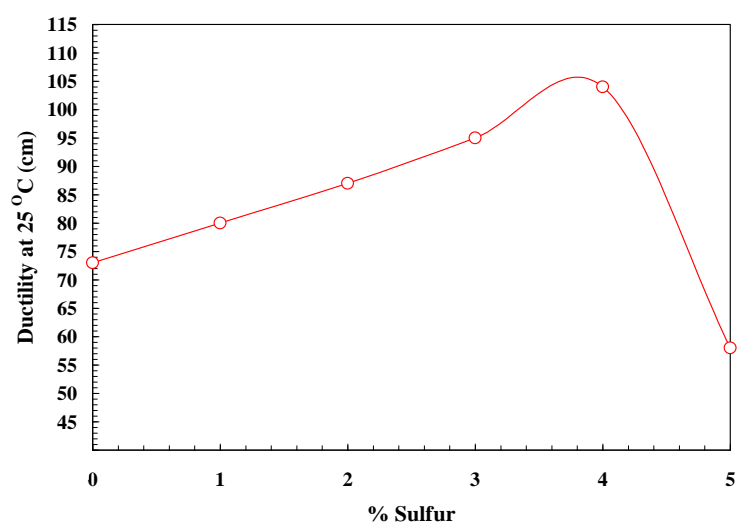

Fig.(9)Ductility vs. Sulfur Percent

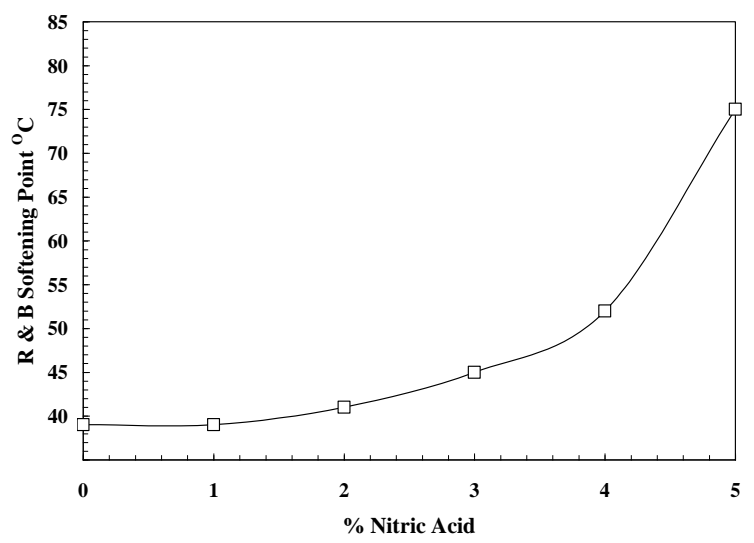

Fig.(11) Softening Point vs. $\mathrm{HNO}_{3}$ percent

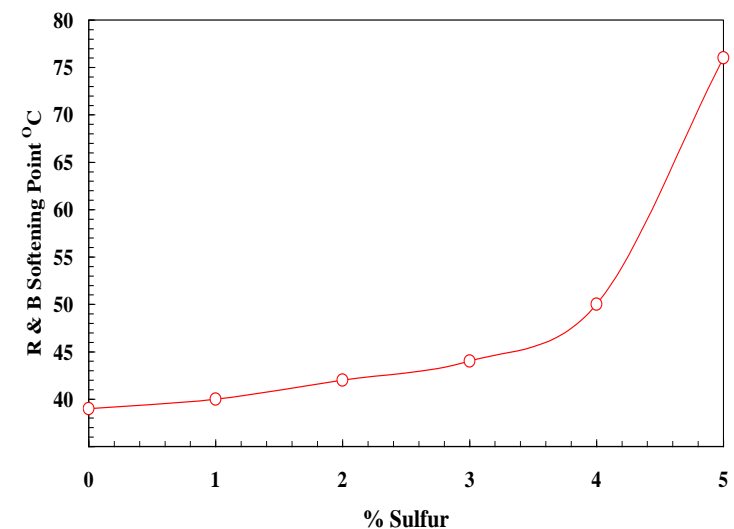

Fig.(8) Softening Point vs. Sulfur Percent

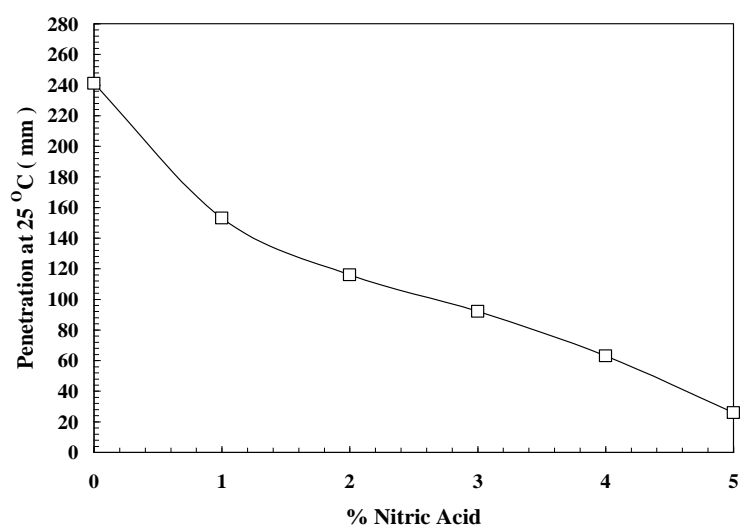

Fig.(10) Penetration vs. $\mathrm{HNO}_{3}$ percent

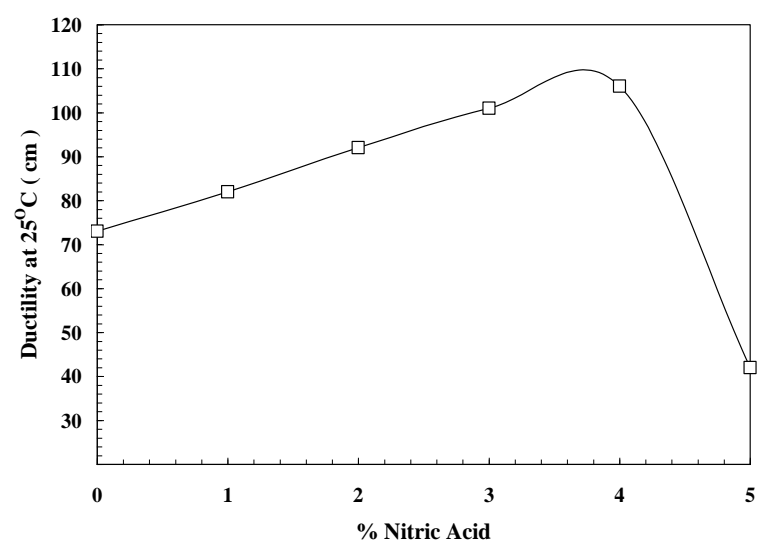

Fig.(12) Ductility vs. $\mathrm{HNO}_{3}$ percent 
Weathering of Treated

\section{Asphaltic Binders}

The results obtained indicated longer used life time of binders exposed by either oxygenation or adding $4 \%$ sulfur or adding 4\% nitric acid to local environmental conditions compared with no treated binder samples which its rheological properties failed within one week. The weathering experiments include exposure of asphalt with additives

to sunlight, water immersion and load for six months continuously for each experiment.

\section{$\underline{\text { Conclusions }}$}

The conclusions that obtained by this study can be illustrated in the following points:

1.Treating of base asphalt by oxygenation, sulfurisation and nitration were evaluated at $260{ }^{\circ} \mathrm{C}$, $220{ }^{\circ} \mathrm{C}$ and $70{ }^{\circ} \mathrm{C}$ respectively.
Treating of base asphalt either by oxygenation or $4 \%$ sulfur or $4 \%$ nitric acid improves the penetration from $241 \mathrm{~mm}$ down to $92 \mathrm{~mm}$, to $68 \mathrm{~mm}$, to 63 $\mathrm{mm}$ respectively, and improves the softening point from $39^{\circ} \mathrm{C}$ up to $49{ }^{\mathrm{O}} \mathrm{C}, 50{ }^{\mathrm{O}} \mathrm{C}$ and $52{ }^{\mathrm{O}} \mathrm{C}$ respectively, also improves the ductility from $73 \mathrm{~cm}$ up to 100 $\mathrm{cm}, \quad 104 \mathrm{~cm}$ and $106 \mathrm{~cm}$ respectively.

2.Treated asphaltic binders by either oxygenation or $4 \%$ sulfur or $4 \%$ nitric acid gave improved longer used life time of the asphalt binder degradation resistance when these binders were exposed to sunlight, water immersion, subjected to load and together at opened environmental conditions for six months. 


\section{$\underline{\text { References }}$}

1. Arnold J. Hoiberg, (1995) "Bituminous Materials: Asphalts, Tars, and Pitches", John Wiely and Sons, Inc., New York, USA.

2. David R. Jones, (1990) "Understanding How the Origin and Composition of Paving - Cored Asphalt Cements Affect their Performance", The University of Texas, Texas USA.

3. Gabrielle Fritschy, Euge'ne Papirer, and Cloude Chombu, (2005) "Sulfur as Supplementary Filler for Composites", Chemistry and Materials Science, New York, USA.

4. Glanville W.H., (1992) "Bituminous Materials in Road Construction", Her Majesty's Stationary Office, London, England.

5. Henry Romagosa and Michel Falkiewicz, (2007) "Phosphoric Acid in Asphalt Modification", MEAUPG-ICL Performance Products LP, Groton, USA .

6. John Bukowski, (1996) "Evaluation and Control of Asphalt Mixture Additive", FHWA Office of Technology Applications, the University of Texas and Austin, Texas, USA.

7. Roman loza, Laurence G., Damman, Roger E., Hyner, Patricia K., and Doolin, (1999) "Cross linkable Polymer - Modified Asphalt and its Method of Preparation", United States Patent 6057390. 